\title{
The Influence Of Educational Resources, Geographic Conditions, Demographic Conditions, Economic Conditions, Population Capacity On Junior High School Gross Participation Rate
}

\author{
Iik Nurulpaik, Johar Permana, Aceng M. Mirfani, Asep Suryana \\ Universitas Pendidikan Indonesia \\ iik.nurulpaik@upi.edu
}

Article received: March 2021; revised: April 2021 ; accepted: April 2021

DOI : $10.17977 /$ um025v5i22021p89

\begin{abstract}
The success of education development will be largely determined by the availability of educational resources as the main variable in providing educational services. Other factors are geographical conditions, demographic conditions, economic conditions, and the capacity of the population itself. This study examines the correlational-contributive relationship between these factors with the Gross Participation Rate (GER) in junior high schools in West Java. The data studied were 2015-2019 (5 years). Quantitative research methods with descriptive analysis. The results showed that the educational resources variable can explain the effect of $88,14 \%$ on the total GER. The geographical condition variable can explain the effect of $63.96 \%$ on the total GER. The demographic condition variable explains the effect of $94.2 \%$ on the total GER and the KE variable contributes approximately $89.21 \%$ to the achievement of the total GER for SMP. The population capacity variable gave a valuable contribution of $37.96 \%$.
\end{abstract}

Keywords: educational resources, participation, quality of education

The quality of education is a concept that is not easy to understand because the criteria used to assess it are influenced by the attributes of when, where, for whom, and by whom the assessment was carried out, as well as the complexity of the teaching and learning process itself. The quality of education is closely related to external or internal quality assurance. In terms of inputs, one assesses quality by considering input factors such as resources, programs, and costs, student-teacher ratios, class size, allocation of funds per student, expenditure per student, teacher salaries, curriculum, textbooks, and inputs. other. The quality of education is also determined by outputs. The quality of education that is most commonly accepted is the student's academic achievement. The quality of education should not be limited to measurable numerical targets such as numeracy, grammar, and language skills, but attention should also be paid to the dimensions of children's social, cognitive, and creative development. These indicators will provide a reflection for implementing the policies needed to be able to improve the quality of the education system with a special focus on the learning outcomes obtained by students. (Joo, et.al, 2010; Cuervo \& Antón, 2013; de Kool \& Bekkers, 2015). The findings show that stakeholders define quality in the same way, highlighting the importance of trained teachers implementing specific teaching practices, strong partnerships with families and communities, critical infrastructure, and government support (Davisa, et.all., 2021).

The concept of quality in education is a relative and subjective concept depending on the point of view. For certain groups, indicators of education quality are marked by the achievement of student learning outcomes in the mastery of certain knowledge, literacy, numeracy, life skills, and the absorption of graduates. One indicator of quality education is when in quantity it can provide broad access for all parties. When in quantity it has met certain achievement targets, then immediately "quality" becomes a new direction of education, including the compulsory level of basic education. In the case of various countries, the tug of war between quantity and quality has become a public policy issue. Attention to 
quality is often biased because of the policy orientation that continues to encourage participation in basic education with the target of mastering minimum competency standards that must be mastered by citizens, for example, the ability to read, write, count (numeracy) in low complexity. (UNESCO, 2000; UNESCO, 2005).

Theoretically, the quality of education output is influenced by a series of educational inputs including factors other than government activities, especially the time spent learning by students and parents, student abilities, family environment, peer groups, and other factors. The output of education is what is produced by the education system (read: schools) to contribute to educational outcomes. The outcome measure in the education sector is generally divided into two components: output for the number of students and achievement of test scores because there is no consensus in the literature on the most appropriate proxies for education, including educational outcomes, test scores, enrollment rates, dropout rates, repetition rates, access, participation rates, literacy rates. (Lee \& Barro, 2001; Atkinson, 2005).

From an international perspective, the definition of quality education can vary. In North America and Europe, the term quality education has many interpretations and is sometimes synonymous with school improvement or school effectiveness. However, international organizations such as the World Bank and UNESCO also use another approach to view the quality of education, namely by using three models to measure quality education: first, the economic model is related to the economist's view of education using quantitative outputs as a measure of quality. This model is based on the human capital theory which states that education is important for economic development and poverty reduction. Second, the humanist tradition emphasizes education as a process, with students at the center of the process. Educational goals include broader social goals such as human rights, social justice, democracy, personal goals. It aims to develop the entire personality as well as creativity and problem-solving skills. Quality education is also seen as a model of educational linkages by emphasizing the importance of linking existing learners' knowledge from the local context. (Barrett et al., 2006; Kumar \& Sarangapani, 2004; Lotz-Sisitka, 2013).

The concept of quality education is based on the premise that educational goals are met. Quality must be seen from the point of view of how society defines educational goals. For example, in the context of the United States and other industrialized countries, it has long been established that the goal of education is to educate the workforce. Whereas in the context of primary and secondary education it is expected to ensure that all students acquire the knowledge, skills, and values necessary for the responsible implementation of citizenship. Another pair of thinking is a greater sense of urgency about the need to improve children's education by further supporting the development of higher-order thinking skills and the ability to apply these skills effectively in real life. (UNESCO, 2004; Wilhoit, 2011; Allum, 2012).

In almost all countries in the world, the achievement of certain knowledge test scores by students is commonly used to measure whether the educational process is being of quality or not. In supporting the effectiveness of schools that are oriented towards meeting the needs of students, it is the teacher's central role in facilitating the implementation of an effective learning process (Ulfatin, et. all., 2020). If a student achieves a high score on the test that is carried out, then the student is considered a product of the educational process that is said to be of good quality. In another view, quality education is not only about the aspect of ability or capacity to think (cerebration) but also concerns aspects of attitudes and knowledge, feelings and thoughts, heart, and also intellectual intelligence. only. All of these domains boil down to how to develop moral and spiritual values and intellectual qualities. Meanwhile, if measuring the quality of education only from the achievement of test scores, does not encourage or reflect efforts to foster moral and ethical behavior. For example, how the quality and scope of educational services for handicapped children, the quality of vocational education, the quality of smart and gifted children are not reflected in the test scores. Test scores will not indicate how well a system meets the broader interests set by society. Therefore, it is too naive to claim that test scores can accurately reflect the quality of public education. (Francis, 1977; Denoyer \& White, 1990). 
The use of this concept carries many meanings and reflects different ideological, social, and political values. Often we understand the concept of "quality of education" as an idea or concept formulation that is relatively difficult to understand. The term quality is often used but not carefully defined. Defining "quality" will have implications for changing the concept of education as well as changing educational practices. Therefore, the notion of quality in education becomes a useful concept in understanding education as a process, so some criteria must be developed to define the intended quality. A significant challenge in developing criteria for quality education relates to the contextual nature of education itself. The concept of quality is subjective, depending on the perceptions of stakeholders. The concept of quality can differ from country to country and according to the priorities, visions, and perspectives of different stakeholder groups, national and local government authorities, parents, children, employers, and education providers themselves (Hawes \& Stephens 1990; Smith, 1995; Sayed 1997; OECD, 2001, Alexander, 2015).

Even in view of Hirst \& Peters, 1970; Bergmann, 1996, in any consideration of the quality of education, the first thing that is needed is to build an understanding of what the true goals of education are. Although the likelihood will vary in defining it depending on context and time, there may also be a minimum boundary of basic learning needs of more universal application which must first be met before more contextual quality issues are considered. Demonstrate that the minimum level of quality in education is fully functional literacy (basic reading and writing skills) and good mastery of basic mathematical operations, including the capacity to apply them to simple everyday problems. From these references to some extent we can define what quality education is.

The quality of this education can at least be viewed from two general perspectives, namely: a quantitative and a qualitative perspective. The two perspectives will have differences in understanding and seeing the quality of education because education will be subjective and multidimensional. From a quantitative perspective, the quality of education can be understood as an observable concept with observable measures/indicators related to quality in the input and output dimensions which economists call the "education production function". These inputs can take the form of for example teachers, infrastructure, textbooks, and output indicators such as test scores, enrollment rates, repetition rates, dropout rates. Meanwhile, qualitative understanding of the quality of education focuses its attention on the subjective nature of the quality of education itself, for example, it focuses more on the process and tries to find out what is happening in schools and classrooms. Where in this case the school is where students develop cognitive skills, attitudes, cultural values, and beliefs. (Coleman et al. 1966; Tikly \& Barrett 2011; Carr, et al. 2015).

Some researchers call the teaching and learning practice process that takes place in the classroom a "black box" area that is rarely studied but is very important for understanding the teaching and learning process and its results. However, this "education production function" approach has evolved into a broad literature on school-effectiveness research that began as a simple educational input-process-output model but now includes a wide range of process and context variables. Predictive quality indicators can include textbooks, teaching time, teacher experience, teacher qualifications, class size, school size, the total number of students enrolled, student: class ratio, teacher: student ratio measure, student: toilet ratio, student: ratio textbooks, class area, teacher teaching load, on the input side with output indicators focused primarily on proxies of educational achievement. (Clifton, et. Al., 1991; Michaelowa, 2001; Chinapah, et. Al., 2003; Arnold, et. Al., 2005; Teddlie \& Reynolds 2000; Black \& Wiliam 2010).

Another perspective is that the human capital approach has represented the idea that education is a process that represents the occurrence of capital stock from which one can expect returns in the future associated with a quantitative perspective. Quality education as measured by cognitive achievement has been shown to have a positive effect on both individual income and economic growth at the aggregate level. Qualitative measures of educational outcomes (school outcomes) and school output including test scores, school attendance rates, and dropout rates are generally interpreted as logical indicators for predicting the individual's future success in the labor market. Likewise, the input of quality indicators is often used in empirical studies because it is relatively easy to observe such as the ratio of students to teachers and students to textbooks, the proportion of teachers with formal pre-service training, the 
presence or absence of facilities such as libraries, laboratories, and toilets. However, what really counts to measure quality is not the number of resources available to schools but the effectiveness of using these resources to strengthen learning (Hanushek \& Rivkin, 2004; Hanushek \& Woessmann 2008; Somerset 2011; Hawkes \& Ugur 2012).

The qualitative perspective on the quality of education shifts the emphasis from measurable input or output to greater attention and in fact, it is relatively difficult to measure it, namely aspects of the process and context. All parties can agree on the importance of placing teaching and learning at the heart of education and at the same time as a place for quality education to take place. Given this complexity, it is understood that education practitioners rely more on input and output indicators that are more easily measured, rather than processes, in making judgments about the quality of education. Process factors are more difficult to measure and take place in the micro scope (Sayed \& Ahmed 2015; Alexander, 2015).

Quality aspects of education are debated concepts and change from time to time according to the context. There is no definite answer to the question of what quality education is. But each perspective offers a different approach to the concept, each with its strengths and weaknesses. Public perceptions about the quality of education also cannot be generalized. But it is a fact, for example, for many people that the idea of the quality of education is determined by the results of national examinations or student admissions at the secondary school level. This shows the value that people place on the instrumental role of education as a means to progress to higher levels of education and to enter the workforce. The dominance of the national exam as an indicator of the quality of education is the most important indicator of a good school. (Tikly and Barrett, 2011; Sifuna \& Sawamura, 2010) (Mbiti, 2016).

Referring to the view (Beeby, 1966), in the 1950s and 1960s, the context in developing countries paid attention to the emphasis on the problem of "quantity", because it was in a "context" where education was faced with a large number of school dropouts and people. illiterate parents, this situation demands more number of schools in quantity than better schools (quality). In a context where people need more education services, according to him, it becomes less relevant when "quality" becomes a culture, but it is also important to describe what the limits of the quality of education are. Furthermore, Beeby conceptualizes the quality of education at three levels. First, at the simplest level, the quality of the classroom that can be observed with the naked eye is associated with the acquisition of a measurable amount of basic knowledge and the expected changes in behavior and attitudes. Second, education must serve the economic objectives of the community in which students live. Third, quality assessments can be carried out against broader social criteria. Meanwhile (Hawes \& Stephens, 1990) conceptualize quality as having three domains: i) efficiency in meeting a series of goals, ii) relevance to human and environmental needs, iii) providing "something more" in pursuit of improving the quality of human life. The term "something more" denotes a level of abstraction that is difficult to define and understand in an objective sense. Measurement of quality at this level is relatively difficult to understand than in technical conceptualizations of quantitative quality. Of course, it is easier to measure quality in terms of teacher qualifications, school infrastructure, and exam results than it is to identify the quality of education that can contribute more to meeting human needs.

Within the framework of the millennium development since 2000, the greater focus is on the quality of educational learning. However, in fact, significant advances in access to basic education are not matched by high levels of cognitive achievement as a reflection of the quality of education and on the other hand, the progress expected for marginalized children is also unclear. defined. Discourse on the quality of education has focused on learning achievement, the relevance of the curriculum to the labor market, and/or the social, cultural, and political environment in which students find themselves and the conditions of learning including teachers and facilities. In practice, the current use of the term "quality" focuses on a relatively more instrumentalist picture of education. The assumption is that learning is something that can be planned, predicted, and measured. (Stenhouse, 1975; Lee, 2006; Hanushek \& Wobmann, 2007; Sayed, 2011). 


\section{METHODS}

This study establishes the following hypotheses: 1 . The influence of educational resource variables on GER. 2. geographic condition variables against GER 3. demographic conditions variables to GER. 4. the variable of economic conditions on GER. 5. Variable capacity of the population to GER. The data describes the achievements of all districts/cities in West Java. The type of data used is secondary data sourced from official data from the West Java Central Statistics Agency, the Regional Education Balance from the Ministry of National Education during the 2015-2019 period. The data were analyzed using SPSS, statistically, the variable was tested to determine its relationship and contribution to the GER.

\section{RESULTS AND DISCUSSION}

Tabel 1. The Effect of Educational Resources on the Total Junior High School GER

\begin{tabular}{lcccc}
\hline Variable & Coefficient & Std. Error & t-Statistic & Prob. \\
\hline C & -28579.66 & 10871.34 & -2.628900 & 0.0096 \\
Education Budget & -16.75934 & 168.6945 & -0.099347 & 0.9210 \\
Number of Schools & 317.6819 & 10.36997 & 30.63478 & 0.0000 \\
Number of Classes & 1120.895 & 304.2369 & 3.684284 & 0.0003 \\
Good Condition Classroom & 0.005767 & 0.001763 & 3.272008 & 0.0014 \\
Damaged Classroom & -0.010187 & 0.008340 & -1.221448 & 0.2242 \\
R-squared & 0.881430 & Mean dependent var & 67413.13 \\
Adjusted R-squared & 0.878715 & S.D. dependent var & 46407.30 \\
S.E. of regression & 16161.83 & Akaike info criterion & 22.24787 \\
Sum squared resid & $3.42 \mathrm{E}+10$ & Schwarz criterion & 22.33396 \\
Log-likelihood & -1497.731 & Hannan-Quinn criteria. & 22.28286 \\
F-statistic & 324.6108 & Durbin-Watson stat & 0.559915 \\
Prob (F-statistic) & 0.000000 & & & \\
\hline
\end{tabular}

Based on the test results as in Table 1, some information that can be explained is as follows:

1. The results of the $F$ test, based on the test results obtained a probability value of 0.000510 $<0.05$, meaning that simultaneously the education budget variables, number of schools, classstudents, class in good condition, class in damaged condition, have a significant effect on GER for Junior High School. (Hypothesis accepted).

2. T-test results:

- The effect of the education budget on GER. Based on the regression test, the probability value is $0.1888>0.05$. This means that the GER is not directly affected by the education budget.

- The effect of the number of schools on GER. Based on the regression test, the probability value is $0.0002<0.05$. This means that GER is influenced by the number of schools.

- Effect of the class number on GER. Based on the regression test conducted, it was obtained a probability value of $0.0003<0.05$. This means that the GER is influenced by the number of classes.

- Effect of good condition class on GER. Based on the regression test carried out, it has a significant effect with a probability value of $0.0014<0.05$. That is, the number of GER is influenced by the good condition of the classroom.

- Effect of damaged classes on GER. Based on the regression test, the effect (negative) was not significant with a probability value of $0.2242>0.05$. This means that the damaged class has a negative effect on GER.

3. $\mathrm{R}^{2}$ test results based on the test results obtained the coefficient of determination (R-squared) of 0.881430 
Tabel 2. Results of Testing the Effect of Geographical Conditions on the Total GER

\begin{tabular}{lcccc}
\hline Variable & Coefficient & Std. Error & t-Statistic & Prob. \\
\hline C & 81.97489 & 1.615020 & 50.75781 & 0.0000 \\
Area & -0.002258 & 0.001324 & -1.706035 & 0.0007 \\
Number of districts & 0.166605 & 0.208098 & 0.800610 & 0.0010 \\
Number of villages & -0.006876 & 0.018466 & -0.372355 & 0.0207 \\
The length of the road & $9.95 \mathrm{E}-05$ & 0.005395 & 0.018443 & 0.9853 \\
Good road conditions & 0.003122 & 0.005904 & 0.528777 & 0.0248 \\
Damaged road conditions & -0.023246 & 0.011625 & -1.999618 & 0.0480 \\
R-squared & 0.639624 & Mean dependent var & 83.31617 \\
Adjusted R-squared & 0.611313 & S.D. dependent var & 8.284402 \\
S.E. of regression & 7.495838 & Akaike info criterion & 6.939190 \\
Sum squared resid & 6180.635 & Schwarz criterion & 7.149376 \\
Log likelihood & -403.8818 & Hannan-Quinn criter. & 7.024540 \\
F-statistic & 4.266647 & Durbin-Watson stat & 0.329918 \\
Prob(F-statistic) & 0.000171 & & \\
\hline
\end{tabular}

From Table 2, some information that can be explained is as follows:

1. F test results, from the test results, obtained a probability value of 0.000000 or $<0.05$. This means that simultaneously the area, the number of districts, the number of villages, the length of roads, good roads, and damaged roads have a significant effect on the total GER for Junior High School. (Hypothesis accepted).

2. T-test results:

- Area to total GER. Based on the regression test, the probability value is $0.0007<0.05$, the beta value (negative). This means that the amount of GER is negatively affected by area size.

- Many districts to total GER. Based on the regression test, the probability value is $0.0010<0.05$. This means that the amount of GER is influenced by the number of districts.

- Number of Villages to total GER. Based on the regression test, it was obtained a probability value of $0.0207<0.05$. This means that the amount of GER is influenced by the number of villages.

- Path length to Total GER. Based on the regression test, the probability value is $0.6653>0.05$. This means that the length of roads in West Java does not affect the increase in the number of GER for Junior High School.

- Good roads to Total GER. Based on the regression test, the probability value is $0.0248<0.05$. This means that the amount of GER is affected by good roads.

- Damaged roads to Total APK. Based on the regression test, the probability value is $0.6254>$ 0.05 , the beta value (negative). This means that an increase in the number of damaged roads has a negative effect on APK.

3. The results of the $\mathrm{R}^{2}$ test, based on the test results, show the coefficient of determination (R-squared) of 0.639624 . 
Tabel 3. Results of Testing the Influence of Demographic Conditions on GER of Junior High School.

\begin{tabular}{lcccc}
\hline Variable & Coefficient & Std. Error & t-Statistic & Prob. \\
\hline C & 62126.84 & 24890.67 & 2.495989 & 0.0138 \\
Total population & 0.037391 & 0.000833 & 44.90269 & 0.0000 \\
Population density & 0.155022 & 0.085316 & 1.817031 & 0.0071 \\
Number of family members & 15432.04 & 6497.996 & 2.374892 & 0.0190 \\
R-squared & 0.941223 & Mean dependent var & 67776.35 \\
Adjusted R-squared & 0.939866 & S.D. dependent var & 46388.43 \\
S.E. of regression & 11375.46 & Akaike info criterion & 21.54570 \\
Sum squared resid & $1.68 \mathrm{E}+10$ & Schwarz criterion & 21.63220 \\
Log-likelihood & -1439.562 & Hannan-Quinn criteria. & 21.58085 \\
F-statistic & 693.9121 & Durbin-Watson stat & 1.115781 \\
Prob(F-statistic) & 0.000000 & & \\
\hline
\end{tabular}

From Table 3, it is obtained a number of information that can be explained as follows:

1. The results of the $\mathrm{F}$ test obtained a probability value of $0.000000<0.05$. This means that simultaneously the number of people, population density per village, number of family members, have a significant effect on the total GER for Junior High School.

2. The results of the t-test are:

- Total Population to Total GER. Based on the regression test, the probability value is 0.0000 $<0.05$. This means that the number of GER is significantly influenced by the number of residents.

- Density Per Village to Total GER. Based on the regression test, the probability value is 0.0071 $<0.05$. This means that the amount of GER is not affected by the population density per village.

- A number of family members to Total GER. Based on the regression test, it was obtained a probability value of $0.0190<0.05$. This means that the number of GER is significantly influenced by the number of family members

3. Based on the results of the $\mathrm{R} 2$ test, it can be seen that the coefficient of determination (R-squared) is 0.941223 .

Tabel 4 The Effect of Economic Capacity on the Total Junior High School GER

\begin{tabular}{llllc}
\hline Variable & Coefficient & Std. Error & t-Statistic & Prob. \\
\hline C & -29056.30 & 64783.83 & -0.448512 & 0.6545 \\
Number of Poor & & & & \\
Population & -0.461980 & 0.014510 & -31.83848 & 0.0000 \\
GDP for Expenditure & 0.008408 & 0.004240 & 1.983227 & 0.0494 \\
Purchasing Power & & & & \\
Index & -538.3441 & 1526.561 & -0.352652 & 0.0072 \\
R-squared & 0.892092 & Mean dependent var & 67413.13 \\
Adjusted R-squared & 0.888772 & S.D. dependent var & 46407.30 \\
S.E. of regression & 15477.26 & Akaike info criterion & 22.16847 \\
Sum squared resid & $3.11 \mathrm{E}+10$ & Schwarz criterion & 22.27607 \\
Log-likelihood & -1491.371 & Hannan-Quinn criter. & 22.21219 \\
F-statistic & 268.6821 & Durbin-Watson stat & 0.966607 \\
Prob(F-statistic) & 0.000000 & & \\
\hline
\end{tabular}

From Table 4, some information that can be explained is as follows:

1. In the $F$ test results, a probability value is obtained of $0.000000<0.05$. This means that simultaneously the poor population, GRDP, purchasing power index have a significant effect on the total GER for Junior High School. 
2. T-test results:

- The effect of the number of poor people on the number of GER. Based on the regression test, the probability value is $0.0000<0.05$. This means that the number of GER is significantly influenced by the number of poor people. The more the number of poor people, the lower the GER.

- The effect of GDP expenditure on total GER. Based on the regression test, the probability value is $0.0490<0.05$. This means that the amount of GER is affected by GRDP.

- The effect of purchasing power on the amount of GER. Based on the regression test, it was obtained a probability value of $0.0072<0.05$. that is done has a significant effect. This means that the amount of GER is not affected by the Purchasing Power Index.

3. The test results of the coefficient of determination (R-squared) are 0.892092 .

Tabel 5 The Effect of Population Capacity on the Total Junior High School GER

\begin{tabular}{lcccc}
\hline Variable & Coefficient & Std. Error & t-Statistic & Prob. \\
\hline C & 148.5184 & 33.04824 & 4.493989 & 0.0000 \\
MYS (Population) & 10.72784 & 5.859420 & 1.830871 & 0.0469 \\
MYS (male) & -0.563460 & 4.086786 & -0.137874 & 0.8906 \\
MYS (female) & -8.594385 & 3.489667 & -2.462810 & 0.0151 \\
Health Level & -1.113174 & 0.531938 & -2.092679 & 0.0384 \\
Gender Empowerment & -0.045258 & 0.108407 & -0.417484 & 0.6770 \\
R-squared & 0.379604 & Mean dependent var & 83.23769 \\
Adjusted R-squared & 0.354822 & S.D. dependent var & 8.237394 \\
S.E. of regression & 7.923232 & Akaike info criterion & 7.021218 \\
Sum squared resid & 8035.534 & Schwarz criterion & 7.150972 \\
Log likelihood & -464.4216 & Hannan-Quinn criter. & 7.073946 \\
F-statistic & 3.151238 & Durbin-Watson stat & 0.159072 \\
Prob(F-statistic) & 0.010231 & & & \\
\hline
\end{tabular}

From Table 4, some information that can be explained is as follows:

1. The results of the F test, based on the table above, can be explained that simultaneously the MYS of the Population, MYS of Male, MYS of Female, Health Level, and gender empowerment index of the GER of West Java Province shows a probability value of $0.010231<0.05$, which means that the variable simultaneously has a significant effect on GER for Junior High School in West Java Province for the period 2015-2019.

2. T-test results:

- Effect of MYS on GER. Based on the regression test carried out, it has a significant effect with a probability value of $0.0469<0.05$. This means that the GER is influenced by the MYS of the population.

- Effect of Male MYS on GER. Based on the regression test carried out, it has a significant effect with a probability value of $0.8906>0.05$. This means that GER is not affected by the MYS of Male.

- The effect of female MYS on GER. Based on the regression test carried out, it has a significant effect with a probability value of $0.0151<0.05$. This means that GER is influenced by female MYS.

- Effect of Health-Life Expectancy on GER. Based on the regression test carried out, it has a significant effect with a probability value of $0.0384<0.05$. This means that GER is influenced by Health Level.

- The effect of gender empowerment on GER. Based on the regression test carried out, it has a significant effect with a probability value of $0.06770>0.05$. This means that GER is not influenced by gender empowerment (women).

3. The test results of the coefficient of determination (R-squared) obtained a value of 0.379604 . 
From the statistical test data, educational resources consisting of the education budget, number of schools, class-student ratio, good condition class, damaged condition class have a significant effect on the participation rate of junior high school education. Therefore, the availability of schools both in quantity and quality needs to continue to be the focus of policy. Because the test also confirms that a good class condition can provide support for GER acceleration and vice versa, a damaged class condition is negative for the number of GER. This means that the government needs to continue to promote improvements so that school conditions are better and can accommodate more students.

From the geographical conditions variable, it is illustrated that simultaneously the factors of area, number of districts, number of villages, length of roads, good roads, damaged roads have a significant effect on the total GER for Junior High School. This is due to the increasingly massive condition of government services, the existence of junior high schools in each sub-district encouraging the acceleration of GER. However, the constraint on area size is also a negative factor for GER. The workaround must be carried out at the sub-district level considering that the test results show that the number of districts has a significant effect in accelerating the GER. Likewise, the factor of the number of villages can be taken into consideration in order to encourage accelerated education in an area. The existence of road infrastructure is not only the length but what is significant is the condition of good road infrastructure and conversely, bad road conditions can have a negative impact on GER acceleration. In the context of West Java. Overall, it can be seen that the coefficient of determination (R-squared) of the geographic conditions on the GER is 0.639624 . This means that geographic conditions contribute approximately $63.96 \%$ to GER. Thus, the variables used as indicators must become an important concern of the government, so that access to education is more open.

The variables of demographic conditions as measured by total population, population density per village, number of family members simultaneously have a significant effect on the total GER for Junior High School. The results of the determination test obtained a value of $94.12 \%$. Thus GER is influenced by variables of population demographic conditions in an area. This means that more and more junior high school-age population are attending school, this means that the large population of West Java is also accompanied by a fairly good level of educational participation.

Referring to the results of statistical testing, GER for Junior High School is also influenced by the number of poor people, the severity of poverty, the amount of GRDP, purchasing power, in terms of increasing population and severity of poverty, a decrease in the economic capacity of residents will have a significant impact on the low GER for Junior High School. Conversely, an increase in economic capacity marked by a reduction in the level of poverty and an increase in the purchasing power of citizens will have a positive impact on the achievement of the GER, the contribution of which is approximately $89.21 \%$. In the context of this study, GER was also simultaneously affected by MYS of population, MYS of male, MYS of female, health level, gender empowerment index had a significant effect on GER for Junior High School. It is interesting that in this study the level of education of women as measured by MYS has a significant effect on the number of GER, while men do not. This can be interpreted that the education of women is an important factor in accelerating educational participation. Likewise, the effect of a significant level of health on GER. This gives a message about the importance of maintaining and improving health services for residents. From the research, it was found that the KP variable was able to explain the effect of approximately $40.9604 \%$ on GER. This also shows the importance of increasing the capacity of the population regarding education and health if you want to accelerate educational participation. An educated and healthy population characterizes good human capital productivity.

Overall, the population capacity variable as measured by MYS of Population, MYS of Male, MYS of Female, Health Level, and gender empowerment (women) simultaneously had a positive influence on GER for Junior High School. This means that the capacity of the population is an important variable and cannot be ignored in efforts to accelerate education. Among these variables, the MYS of the population, the MYS for the female population, and the level of health had a significant effect, while the MYS for men and gender empowerment was not correlative and significant). Overall the population capacity variable is able to explain the effect of $37.96 \%$ on GER. 


\section{CONCLUSIONS AND SUGGESTIONS}

\section{Conclusions:}

1. Factors that have a positive-significant effect on the number of GER for junior high schools in West Java are a number of schools, good class conditions, women's education, population health level, women's empowerment, good road conditions.

2. Factors that have a negative effect on the number of GER for junior high schools in West Java are damaged class conditions, the number of poor people, poverty severity, total GRDP.

3. Area, population, population density, number of family members can be positive for GER if you get access to education services and vice versa.

\section{Suggestion:}

1. Based on the conclusions drawn, local governments must consistently increase the capacity of education infrastructure and public transportation infrastructure. In addition, education and health services for women must also receive serious attention because they are significant for increasing school participation. Sub-district expansion can be a fairly good option if you want to accelerate the GER for Junior High School.

\section{REFERENCES}

Alexander, R. J. 2015. "Teaching and learning for all? The quality imperative revisited." International Journal of Educational Development, (Onilen), (https://EconPapers.repec.org/RePEc:eee:injoed:v:40:y:2015, diakses 20 Januari 2021)

Allum, J. 2012. Minister's Message. (http://www.edu.gov.mb.ca/minister.html, diakses 20 Januari 2021)

Arnold, M. L., Newman, J. H., Gaddy, B. B., \& Dean, C. B. 2005. A look at the condition of rural education research: Setting a difference for future research. Journal of Research in Rural Education, 20(6), (online), ( http://www.umaine.edu/jrre/20-6.pdf, diakses 20 Januari 2021).

Atkinson, A. 2005. Atkinson review: Final report. Measurement of Government Output and Productivity for Government Accounts: Palgrave, MacMillan, Basingstoke, (Online). (https://www.semanticscholar.org/ paper/The-Atkinson-Review\%3A-Final-Report, diakses 20 Januari 2021)

Barrett, A.M. 2011. "An education Millennium Development Goal for quality: complexity and democracy." Compare: A journal of comparative and international education, 41(1): 145-148. (online), (https://doi.org/1 0.1080/03057925.2011.534853, diakses 22 Januari 2021)

Beeby, C.E. 1966. "The quality of education in developing countries." Cambridge MA: Harvard University Press. (online), (https://www.hup.harvard.edu/results-list.php?author=4255, diakses 22 januari 2020)

Bergmann, H. 1996. Quality of Education and the Demand for Education: Evidence from Developing Countries. International Review of Education, 42(6): 581 - 604. (Online), (https://www.jstor.org/stable/3445008?seq=1, diakses tanggal 23 januari 2021)

Black, P. \& Wiliam, D. 2010. "Inside the black box: Raising standards through classroom assessment." Phi Delta Kappan 92(1), 81-90. (Online), (https://doi.org/10.1177/003172171009200119, diakses 22 januari 2021)

Carr-Hill, R.; Rolleston, C.; Pherali, T.; Schendel, R. (2015). "The effects of school-based decision making on educational outcomes in low-and middle-income contexts: A systematic review." The Campbell Collaboration. (Online), (https://assets.publishing.service.gov.uk/media/57a089b7e5274a31e000021e/Carr-Hill SBDM Protocol.pdf, diakses 24 Januari 2021)

Chinapah, V., Cars, M., Grinberg, S. 2013. Global Efforts towards Quality Education for All: Evidence and Reflections from an International and Comparative Educational Perspective. Journal of Education and Research August 2013, Vol. 3, No. 2, pp. 39-58. (online), (doi: http://dx.doi.org/10.3126/jer.v3i2.8397.

Cuervo, C.E., \& Antón, N.V. (2013). Spatial Double Generalized Beta Regression Models: Extensions and Application to Study Quality of Education in Colombia. Journal of Educational and Behavioral Statistics, 38(6), 604-628. (online), (https://doi.org/10.3102/1076998613499779, diakses 24 januari 2021)

Coleman, J. S., \& Department of Health USA. (1966). Equality of educational opportunity (Vol. 2). Washington, DC: US Department of Health, Education, and Welfare, Office of Education. (Online), (https://files.eric. ed.gov/fulltext/ED012275.pdf, diakses 24 januari 2021) 
Clifton, R.A., Williams, T. \& Clancy, J. 1991. The Academic Attainment of Ethnic Groups in Australia: A Social Psychological Model. Sociology of Education, Vol. 64, No. 2 (Apr., 1991), pp. 111-126. American Sociological Association. (online), (https://doi.org/10.2307/2112882\#, diakses tanggal 24 januari 2021)

Davisa, D., Miller, D., Mrema, D., Matsoai, M., Mapetla, N., Raikes, A., and Burtona, A. 2021. Understanding perceptions of quality among early childhood education stakeholders in Tanzania and Lesotho: A multiple qualitative case study. Social Sciences \& Humanities Open, Volume 4, Issue 1. https://www.sciencedirect. com/journal/social-sciences-and-humanities-open

Denoyer, R. A., \& White, M. 1990. Tests Fallible Indicators of Educational Quality. NASSP Bulletin, 74(523), 49-52. (online), (https://doi.org/10.1177/019263659007452310, diakes 24 januari 2021)

de Kool, D., \& Bekkers, V. 2015. The Perceived Impact of Open Inspection Data on the Quality of Education in Dutch Primary Schools: A Parent Perspective. Social Science Computer Review. (online), (https://doi. org/10.1177/0894439314560853, diakses 24 Januari 2021)

Francis, N. C. 1977. Quality Education and Equality of Educational Opportunity. NASSP Bulletin, 61(409). (onlien), (doi: https://doi.org/10.1177/019263657706140903, diakses 24 Januari 2021)

Hanushek, E.A. \& Rivkin, S.G. 2003. Does Public School Competition Affect Teacher Quality?. the Economics of School Choice: Chicago: University of Chicago Press. (online), (http://hanushek.stanford.edu/sites/default/ files/publications/Hanushek\%2BRivkin\%202003\%20EconSchChoice_0.pdf, diakses 24 Januari 2021)

Hanushek, E., \& Woessmann, L. 2008. The Role of Cognitive Skills in Economic Development. Journal of Economic Literature, 46(3): 607-668. (online), (doi: 10.1257/jel.46.3.607, diakses 24 Januari 2021)

Hawes, H. \& Stephens, D. 1990. Questions of quality: primary education and development. Harlow: Longman.

Hawkes, D. \& Ugur, M. 2012. Evidence on the relationship between education, skills and economic growth in lowincome countries: A systematic review. EPPI-Centre, Social Science Research Unit, Institute of Education. London: University of London. (Online), (https://eppi.ioe.ac.uk/cms/Portals/0/PDF\%20reviews\%20and\%20 summaries/Education\%20skills\%20growth\%202012Hawkes\%20report.pdf, diakses 24 Januari 2021)

Hirst, P.H. \& Peters, R.S. 2012. The Logic of Education. USA: Routledge. (online), (https://books.google.co.id/ books?id=9nP31 rw-eJ4C\&printsec $=$ frontcover\#v=onepage \&q\&f=false, (Online), diakses 24 januari 2021)

Joo, H., Oh, Beom-ho; Yun, Chung-Il. (2010). An analysis of the relationship between The quantity and quality of education: Focusing on korea and oecd countries. Policy Futures in Education Vol. 8 Number 6. (online), (http://dx.doi.org/10.2304/pfie.2010.8.6.607, diakses 25 januari 2021)

Kumar, K., \& Sarangapani, P. 2004. History of the quality debate. Contemporary Education Dialogue, 2(1), 3052. (Online), (https://doi.org/10.1177/097318490400200103, diakses, 25 Januari 2021)

Ki-moon, B. (2012). Global Education First Initiative. (Online), (http://www.globaleducationfirst.org/289.htm, diakses tanggal 25 Januari 2021).

Lee, J.W., \& Barro, R. 2001. Schooling Quality in a Cross-Section of Countries. Economica, 68(272), 465488. (Online), (doi:10.1111/1468-0335.d01-12, diakses tanggal 25 Januari 2021)

Lotz-Sisitka, H. 2013. Conceptions of quality and learning as connection: Teaching for relevance. Southern African Journal of Environmental Education, 29, 25-38. (Online), ( Downloads/122256-Article\%20Text-335615-110-20150917.pdf, diakses tanggal 25 Januari 2021)

Mbiti, I. M. 2016. The need for accountability in education in developing countries. The Journal of Economic Perspectives , 30(3): 109-132. (Online), (doi:_10.1257/jep.30.3.109 http://www.oecd.org/italy/ economicsurveyofitaly2009towardsbetterschoolsandmoreequalopportuniti esforlearning.htm, diakses 25 Januari 2021)

OECD (2009) PISA 2009 Results: what students know and can do. Paris: OECD. (Online), (http://www.oecd.org/ pisa/pisaproducts/48852548.pdf, diakses 25 Januari 2015)

Sayed, Y. \& Ahmed, R. 2015. Education quality, and teaching and learning in the post-2015 education agenda. International Journal of Educational Development, 40: 330-338. (Online), (doi: 10.1016/j. ijedudev.2014.11.005, diakses 26 januari 2021)

Sayed, Y. (1997). The concept of quality in education: a view from South Africa. Dalam Watson, K.; Modgil, C.; Modgil, S. (Penyunting), Educational dilemmas: debate and diversity. Vol. 4: Quality in education. Cassell: London. (Online), (https://www.fly-unicorn.com/LP_TA/index.cfm?T=439383, diakses 26 Januari 2021)

Smith, K. B., \& Meier, K. J. 1995. Politics and the Quality of Education: Improving Student Performance. Political Research Quarterly, 48(2), (Online), (https://doi.org/10.1177/106591299504800206, diakses 26 Januari 2021) 
Somerset, A. (2011). Strengthening educational quality in developing countries: the role of national examinations and international assessment systems. Compare: A journal of comparative and international education, Vol. 41, 141-144. (Online), (https://doi.org/10.1080/03057925.2011.534851, diakses 28 Januari 20221)

Stenhouse, L. (1975). An introduction to curriculum research and development. London: Heinemann.

Sifuna, D.N. \& Sawamura, N. 2010. Challenges of Quality Education in Sub-Saharan African Countries. New York: Nova Science Publishers, Inc. (Online), (http://aadcice.hiroshima-u.ac.jp/e/publications/sosho4_1-01_02. pdf, diakses 27 januari 2021)

Tikly, L. \& Barrett, A. (2011). Social Justice, Capabilities and the Quality Education in Low Income Countries. International Journal of Educational Development, 31(1) 3-14. (Online), ( doi: https://doi.org/10.1016/j. ijedudev.2010.06.001, diakses 26 Januari 2021)

Tikly, L., \& Barrett, A. M. 2013. Education quality and social justice in the global south:Challenges for policy, practice and research. New York: Routledge.

national examinations and international assessment systems. Compare: A journal of comparative and international education, Vol. 41, 141-144. (Online), (doi: https://doi.org/10.1080/03057925.2011.534851, diakses 26 januari 2021)

Teddlie, C. \& Reynolds, D. (Eds.). 2000. The International Handbook of School Effectiveness Research. Falmer Press: London. (Online), (https://www.researchgate.net/publication/4836590_The_International_Handbook of_School_Effectiveness_Research_Charles_Teddlie_and_David_Reynolds_Falmer_Press_London_and New_York_2000_pp_xiii411_Price_4495_paperback, 26 Januari 2021)

Ulfatin, N., Mustiningsih, Sumarsono, R.B. and Yunus, J.N. 2020. School-based management in marginal areas: Satisfying the political context and student needs. Management in Education 1-11. journals.sagepub.com/ home/mie DOI: 10.1177/0892020620959739

UNESCO. 2004. The quality imperative: Education for all global monitoring report 2005. (Online), (http:// unesdoc.unesco.org/images/0014/001410/141019e.pdf, 26 januari 2021)

UNESCO. 2005. Contributing to a more sustainable future: Quality education, life skills and education for sustainable development. (Online), (https://unesdoc.unesco.org/ark:/48223/pf0000141629, diakses 27 Januari 2021)

Wilhoit, G. 2011. Foreword. Dalam V. B. Mansilla \& A. Jackson, Educating for global competence: Preparing our youth to engage the world (pp. viii-ix). Washington, DC: Council of Chief. (Online), (https://asiasociety.org/ files/book-globalcompetence.pdf, 27 Januari 2021) 